\title{
Educational Attainment, Teaching Experience, Professional Development and Self- Efficacy as Predictors of Chemistry Content Knowledge: Implication for the Development of a National Promotion Examination
}

Jina Denise R. Galiza ${ }^{1}$, Rhodora F. Nicdao ${ }^{2}$, and Armando M. Guidote Jr. ${ }^{3,4^{*}}$

${ }^{1}$ MS Science Education Program, School of Science \& Engineering, Loyola Schools, Ateneo de Manila University, Katipunan Ave., Loyola Heights, Quezon City

${ }^{2}$ Department of Education, School of Social Sciences, Loyola Schools, Ateneo de Manila University, Katipunan Ave., Loyola Heights, Quezon City

${ }^{3}$ Department of Chemistry, School of Science \& Engineering, Loyola Schools, Ateneo de Manila University, Katipunan Ave., Loyola Heights, Quezon City

${ }^{4}$ Philippine Institute of Pure and Applied Chemistry (PIPAC), Ateneo de Manila University Campus, Katipunan Ave., Loyola Heights, Quezon City

\begin{abstract}
This study examined teachers' content knowledge (CK) in chemistry and its relationship to teachers' chemistry background, teaching experience, involvement in professional development and self-efficacy It was further investigated which variables predicted the level of content knowledge (CK) of one hundred public secondary chemistry teachers. The data shows that the majority of science teachers have low level of CK in Chemistry. Teaching experience, professional development, chemistry background, and selfefficacy were significantly related to the CK of teachers. Teachers' professional development and self-efficacy predicted the CK of teachers.
\end{abstract}

Keywords: teaching experience; content knowledge; self-efficacy; chemistry background; professional development

\section{INTRODUCTION}

There is a major concern on the teaching of science in the Philippines due to the poor performance of the Philippines in benchmarking tests such as the Trends in International Mathematics and Science Studies (TIMMS). Because of the direct interaction between teachers and students, the quality of teaching may have a positive or negative effect on student learning. Quality can be equated with competency, efficiency and a teacher's adequate knowledge of content.

Teacher's content knowledge (CK) is the foundation to effectively teach (McConnell, et al, 2013). Teachers need to be strongly grounded on scientific concepts to be able to deliver them in a manner that is comprehensible to students. Teachers' content 
knowledge (CK) serves as an essential tool in teaching science and also integrating concepts in pedagogy (Satau et. al. 2014).

With the $\mathrm{K}$ to 12 reform, there is a greater concern with regard to the ability of Science teachers to teach properly. One of the main features of the K to 12 curriculum is the use of spiral progression approach. Topics in Life Sciences, Physics, Chemistry and Earth Science are presented in an increasing level of difficulty from Grade 7 to 10, thus, promoting and deepening the understanding and mastery of the science concepts among learners. Additionally, the content and skills are presented in a multidisciplinary and interdisciplinary approaches. The main purpose of these approaches is to provide connection om among science subjects and other disciplines.

For many years, in-service science teachers are experts in a particular subject (i.e., Chemistry was taught by chemistry majors, Biology was taught by Biology majors). With the curricular change, science teachers are now expected to teach all disciplines. This poses a challenge for science teachers as the expectation is that they are adept in all the science subjects.

It has been found that non-chemistry science teacher's knowledge is deficient in teaching chemistry concepts in high school, in spite of their possession of an academic degree (Kind, 2014). The science educator may have a field of specialization or major in college, but then again it is indispensable that a teacher should have the breadth of knowledge across other science disciplines (DOST-SEI, UPNISMED, 2011).

The main objective of this study is to assess the level of chemistry CK of teachers in Grade 7 to 10. This study aims to find out if variables such as (1) Chemistry Background (CB), (2) Teaching Experience (TE), (3) Involvement in Professional Development (PD) Activities and (4) Self-Efficacy (SE) are predictors of CK of teachers. The variables were correlated to the level of CK in chemistry. This work may serve as a baseline of teacher performance. The results of the work may also be used as a basis for drafting a national promotional examination for teachers. This proposed examination is meant to strongly encourage teachers to improve their CK.

The following terms, are defined in accordance with the context of this study:

1. Content Knowledge (CK). In this study, content knowledge refers to the levels of teachers' mastery of scientific concepts, principles, and theories in chemistry, as shown by the scores obtained in the Chemistry Content Knowledge Test.

2. Chemistry Background (CB). This term refers to the academic preparation of the teacher in the field of chemistry which includes the units earned in chemistry from their baccalaureate degree, graduate and post graduate programs.

3. Teaching experience (TE). This term refers to the teachers' number of years in teaching.

4. Professional Development (PD) Activities. These include the following: courses/workshops and conferences/seminars which focus on content, pedagogy or both, observation visits to another school, research, mentoring/coaching in a formal arrangement, peer observation, reading professional literature, and informal dialogue with peers on how to improve teaching. In this study, professional development refers to the frequency and duration of their participation within the past 12 months.

5. Self-Efficacy (SE). This term refers to the beliefs of teachers in their own capacity to influence student performance, a judgment of their own capabilities to organize and execute lessons to effect learning among students as indicated by scores obtained in the Self-Efficacy Scale.

6. Promotion. This term refers to the advancement of teachers from one position with an increase in duties and responsibility and accompanied with the increase in salary.

Framework. Content knowledge (CK). Content knowledge $(\mathrm{CK})$ is defined as the disciplinary conceptual knowledge of the teacher. It is considered necessary for the teacher to teach concepts, principles and theories. McConnell et al. (2013) described a teacher's CK as the foundation to effectively teach inside the classroom. Teachers need to understand and master the scientific concepts that they teach, to be able to perform more complex tasks in teaching science. Complex tasks are the following: identifying misconceptions, presenting models that give accurate depictions of scientific concepts, constructing tasks that will engage learners to inquiry more, and explaining complex ideas connected to the core idea.

Research on both content and pedagogical knowledge has long been of interest to science educators. They have one common goal, the pursuit of improving science education for every single learner. An effective science teacher is confident in teaching the subject matter. It simply implies that the teacher 
knows the content and can effectively teach using appropriate strategies. Studies show that CK alone is insufficient to effectively teach science. A study by Fleer (2009) found that the lack of science CK causes the incapability of educators to teach science efficiently. The factor accountable for the variances in the quality of teaching is the differences in the teacher's CK (Shallcross, et al 2002).

Pedagogical Content Knowledge (PCK) is defined as understanding appropriate instructional practices for teaching a specific subject which, makes it easier for students to understand science (Shullman, 1986). Science CK is rarely studied than PCK despite the fact that strong $\mathrm{CK}$ is required for strong PCK (Kaya, 2009; Van Driel et. al 2002). In addition, Science CK and pedagogy are both difficult to master. Nonetheless, the development of both Science CK and PCK are essential in scientific understanding, thus focusing on science $\mathrm{CK}$ too is very essential for research.

Diamond et al. (2014) found that professional development intervention helped improve teachers' CK. Teachers who participated in an intervention program demonstrated significant increase in the teacher science knowledge (Diamond, et al., 2014). Consequently, increased CKresulted to betterstudent performance. This study shows that assessment of teachers' CK provides important information needed by educators to improve, plan and develop a good design for professional development. We also hope that a National Promotional Examination for Public School Teachers can be considered to force teachers to improve their $\mathrm{CK}$.

Figure 1 illustrates the objective of this work.

\section{METHODOLOGY}

This study utilized the descriptive correlation method of research (Gay \& Airasian, 2003, Calmorin \& Calmorin, 2012). It was conducted in ten public secondary high schools in the city of Manila. Participants were grades 7 to 10 science teachers. In the $\mathrm{K}$ to 12 program, these teachers are expected to teach all science subjects including chemistry. Five principals and head teachers also participated in the study. They were key informants with regard to the promotion system. Four instruments were used in the study.

Chemistry CK Test. Construction. The test consisted of 51 items and was worth a total of 60 points. There were 42 multiple choice questions and 9 short response questions. The nine (9) short response questions, were directly taken from the TIMSS. Chemistry content experts reviewed the

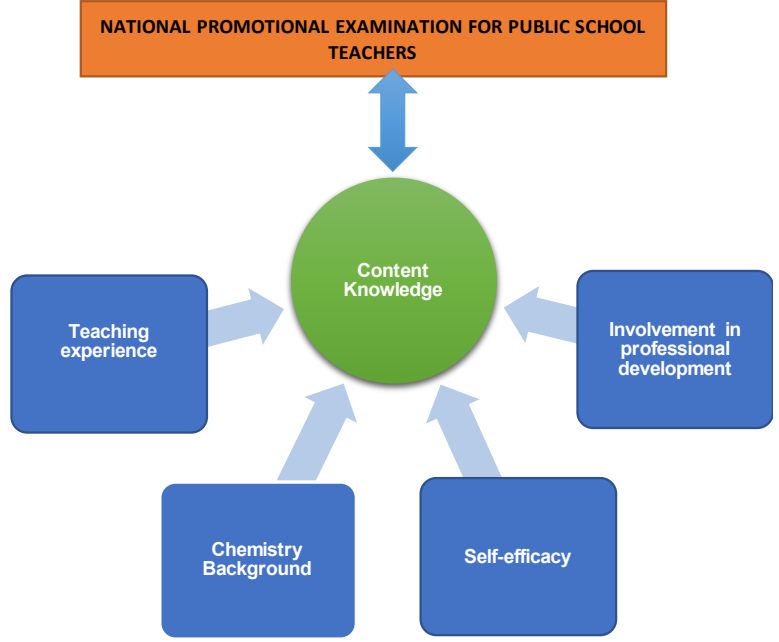

Figure 1: The research paradigm shows that chemistry background, teaching experience, involvement in professional development and self-efficacy are predictors of Content Knowledge (CK) in Chemistry. The results will serve as basis for a proposed National Promotional Examination for Public school Science Teachers. The National Promotional Examination is a mechanism to help teachers develop mastery of content knowledge.

items and provided recommendations concerning the alignment of each item with the content specifications of the test (Supporting Information $\mathrm{N})$. Based on the content review recommendations, items were revised and additional items were added to meet content specifications.

The final draft of the CK test was piloted to a group of students who were comparable to the target participants. The pilot group consists of graduate students (science teachers) enrolled in Master of Arts in Education, Major in Science Education from The National Teachers College. The teachers were able to complete the test in 1 hour and 45 minutes and minor feedback regarding the questionnaire was noted; there were no major issues reported with the test items.

Item Analysis. Item analysis was used on the chemistry content knowledge test to determine the difficulty and discrimination index of each item. (Supporting Information M)

The final version of the Chemistry CK Test (Supporting Information $\mathrm{H}$ ) was developed to provide a comprehensive measure of teachers' level of CK in Chemistry. This instrument has been aligned with the K-12 Curriculum. Table 1, shows the Chemistry concept area by grade level. Recall questions fell under the easy level, understanding and application questions fell under the moderate level while analysis questions fell under the difficult level. For every correct answer obtained in the multiple 
choice, one point was allocated. Short response items were worth two points for every correct response, one point for partially correct response and zero point for no answer or incorrect answer. A rubric for short response questions, items was utilized (Supporting Information I). The highest possible score is sixty (60) points. The reliability of this instrument (only for the multiple question part) was proven to be high, with the Kuder-Richardson Formulae (KR20) of 0.9 (See Supporting Information S).

Table 1. Chemistry Concept Area by Grade Level.

\begin{tabular}{llc}
\hline Grade Level & Chemistry Concept Area & No. of Items \\
\hline Grade 7 & - Substances and Mixtures & 11 \\
& - Elements and Compounds & \\
& - Acid and Bases & \\
& Metals and Non-metals & \\
\hline Grade 8 & - Matter and its properties & 13 \\
& - Atomic Properties & \\
& - Atomic Structure \\
& - Particle Nature of Matter & \\
& Periodic Table of Elements & \\
\hline Grade 9 & - Chemical bonding & 10 \\
& - Organic Compound & \\
\hline Grade 10 & - Gas laws & 17 \\
& - Chemical Reactions & \\
\hline & Biomolecules & $\mathbf{5 1}$ \\
\hline & Total & \\
\hline
\end{tabular}

The levels of CK in chemistry were analyzed and interpreted using the score range as shown in the Table 2:

Table 2. Chemistry CK Test Interpretation of Scores.

\begin{tabular}{cc}
\hline Score Range & Interpretation \\
\hline $55-60$ & Advanced \\
\hline $49-54$ & Proficient \\
\hline $43-48$ & Approaching Proficient \\
\hline $37-42$ & Developing \\
\hline 36 and below & Beginning \\
\hline
\end{tabular}

Chemistry Background (CB) and Teaching Experience (TE) Checklist. A checklist (Supporting Information D) was developed and provided a basis for measuring the $\mathrm{CB}$ and $\mathrm{TE}$ of respondents. The highest possible score for $\mathrm{CB}$ is 150 points. Table 3 , shows the corresponding equivalent point for each program. The CB was examined by looking at the number of chemistry units in each program. The equivalent points were all based on the number of earned units in Chemistry.
Table 3. Chemistry Background Checklist and corresponding Equivalent Point.

\begin{tabular}{ll}
\hline Bachelor's Courses & Equivalent Point \\
\hline Bachelor of Secondary Education major in: & \\
\hline Biological Science & 20 \\
\hline Biology and other courses related to biology & 20 \\
\hline $\begin{array}{l}\text { Chemistry and other courses related to chemistry } \\
\text { (BS Chemistry, BS Chemical Engineering, BS }\end{array}$ & 50 \\
Industrial Chemistry) & \\
\hline General Science and other courses related to & 15
\end{tabular}

\begin{tabular}{lc}
\hline Physical Science & 15 \\
\hline Physics & 8 \\
\hline $\begin{array}{l}\text { Others: BS Natural Science, BS Nursing, BS } \\
\text { Geology }\end{array}$ & 10
\end{tabular}

$\begin{array}{ll}\text { Geology, BSED Natural Science } & \text { Equivalent Point }\end{array}$

\begin{tabular}{|c|c|}
\hline \multicolumn{2}{|l|}{ MA in Education major in } \\
\hline Biological Science & 0 \\
\hline Biology and other courses related to Biology & 0 \\
\hline Chemistry & 50 \\
\hline Curriculum and Instruction & 0 \\
\hline Educational Administration & 0 \\
\hline Educational Management & 0 \\
\hline Natural Science & 0 \\
\hline Physics & 0 \\
\hline \multicolumn{2}{|l|}{ MS in } \\
\hline $\begin{array}{l}\text { Science Education and other courses related to } \\
\text { Science Education (MA Science Education, MS } \\
\text { General Science, MA General Science) }\end{array}$ & 10 \\
\hline Secondary Education & 0 \\
\hline \multicolumn{2}{|l|}{ MS in Teaching major in } \\
\hline Biology & 0 \\
\hline $\begin{array}{l}\text { Chemistry and other courses related to chemistry } \\
\text { (MS Chemistry Education) }\end{array}$ & 50 \\
\hline $\begin{array}{l}\text { Physics and other courses related to physics (MS } \\
\text { Physics) }\end{array}$ & 0 \\
\hline \multicolumn{2}{|l|}{ Others: } \\
\hline $\begin{array}{l}\text { MS Natural Science, MA Developmental } \\
\text { Education, }\end{array}$ & 0 \\
\hline MA Computer Science & 0 \\
\hline Doctoral Courses & Equivalent Point \\
\hline \multicolumn{2}{|l|}{ Doctor of Education major in } \\
\hline Biology & 0 \\
\hline Chemistry & 50 \\
\hline Educational Leadership & 0 \\
\hline Educational Management & 0 \\
\hline General Science & 0 \\
\hline \multicolumn{2}{|l|}{ Ph.D. in Science Education major in } \\
\hline Biology & 0 \\
\hline Chemistry & 50 \\
\hline Physics & 0 \\
\hline \multicolumn{2}{|l|}{ Others: } \\
\hline Ph.D. Educational Management & 0 \\
\hline Ph.D. Science Education & 0 \\
\hline Ph.D .Math & 0 \\
\hline
\end{tabular}


The teacher's background in chemistry was analysed and interpreted using the score range in Table 4:

Table 4. Interpretation of Teacher's Background in Chemistry.

\begin{tabular}{cc}
\hline Score Range & Interpretation \\
\hline $1-30$ & Very Low \\
\hline $31-60$ & Low \\
\hline $61-90$ & Moderate \\
\hline $91-120$ & High \\
\hline $121-150$ & Very High \\
\hline
\end{tabular}

The equivalent points was developed to measure the TE. Based on the ranking system of Dep ED, the scores were analyzed and interpreted using the score range in Table 5 below.

\section{Table 5. Teaching Experience (Years).}

\begin{tabular}{ccc}
\hline $\begin{array}{c}\text { Equivalent } \\
\text { Point }\end{array}$ & $\begin{array}{c}\text { Teaching Experience } \\
\text { (Years) }\end{array}$ & Interpretation \\
\hline 50 & 21 years or more & Master Teacher 3 \\
\hline 40 & $16-20$ years & Master Teacher 2 \\
\hline 30 & $11-15$ years & Master Teacher 1 \\
\hline 20 & $5-10$ years & Senior \\
\hline 10 & Less than 5 years & Junior \\
\hline
\end{tabular}

Professional Development (PD) Checklist. A checklist (Supporting Information E) was developed and utilized to measure the PD of teacher respondents. The checklist included the specific PD activities and the average duration per PD they have attended. The highest possible score for this checklist is 76 points. The PD checklist consists of thirteen (13) activities, the different PD activities were the following: (1) courses/workshops which focus on content, pedagogy or mixed (content and pedagogy), (2) conferences/seminar that focus on content, pedagogy or mixed (content and pedagogy), (3) observation visit to another school, (4) or research work whether individual or collaborative, (5) mentoring/coaching in formal school arrangement, (6) peer observation, (7) reading professional literature, and (8) informal dialogue with peers on how to improve teaching. The checklist measured the thirteen (13) PD activities by assigning an equivalent point to the number of participation per school year and also the average duration (hours per day) (shown in Table 6). The number of participation of teacher respondents in a school year were noted as 0, 1-4, 5-8, and 9-12. The equivalent point is the following: 0: 1 point, 1-4: 2 points, 5-8: 3 points, 9-12: 4 points and 0 point for no answer. Average duration (hours per day) were noted as 1-2, 3-4, 5-6, and 7-8. The equivalent point is the following: 1 point, 2 points, 3 points and 4 points, respectively (shown on Table 6). The reliability of this instrument was proven to be high. The Cronbach alpha computed value is of 0.86. (Supporting Information R)

Table 6. Professional Development Activities \&
Duration and Corresponding Equivalent Points.

\begin{tabular}{cc}
\hline Frequency & Equivalent Point/s \\
\hline 0 & 1 \\
\hline $1-4$ & 2 \\
\hline $5-8$ & 3 \\
\hline $9-12$ & 4 \\
\hline Duration & Equivalent Point/s \\
\hline $1-2$ & 1 \\
\hline $3-4$ & 2 \\
\hline $5-6$ & 3 \\
\hline $7-8$ & 4 \\
\hline No answer & $\mathbf{0}$ \\
\hline
\end{tabular}

The study also devised and utilized a PD checklist. The scores were analyzed and interpreted using the score range as shown in a Table 7 below.

Table 7. Professional Development Checklist Interpretation.

\begin{tabular}{cc}
\hline Score Range & Interpretation \\
\hline $1-19$ & Very Low \\
\hline $20-38$ & Low \\
\hline $39-57$ & High \\
\hline $58-76$ & Very High \\
\hline
\end{tabular}

Self-Efficacy Scale (SE). The SE Scale (Supporting Information G) was used in this study. This scale consisted of thirteen (13) items, which were answerable using a 4- point scale. One or (1) means Very Little, 2 means Little, 3 means Much and 4 means Very Much. This scale was designed to assess teachers' self-efficacy in order to gain understanding in the difficulties encountered by teachers in their school activities. The respondents were asked to answer each question by considering the combination of their current abilities, resources, and opportunities to each of the position included in the items (Tschannen - Moren \& Woolfolk Hoy, 2001). The reliability of the scale was proven to be high, with the computed Cronbach alpha value of 0.95 .

The study also devised and utilized a SE Scale. The scores are analyzed and interpreted using the score range as shown in a Table 8 below: 
Table 8. Self-Efficacy Scale Interpretation of Scores.

\begin{tabular}{cc}
\hline Score Range & Interpretation \\
\hline $1-13$ & Very Low \\
\hline $14-26$ & Low \\
\hline $27-39$ & High \\
\hline $40-52$ & Very High \\
\hline
\end{tabular}

Interview Guide. Individual interview (Supporting Information F) which lasted for (10) minutes each was held using a semi-structured protocol. The interview focused on training, promotion, and improvement of science content knowledge. Ten (10) teacher-respondents, five (5) head teachers in science and five (5) school principals were interviewed.

Data Collection. A consent letter was given to participants stating the objectives of the research prior to data gathering (Supporting Information C). The CB and TE checklist, PD checklist, and SE scale were given before respondents took the chemistry CK test. The consent assured the participants that all responses and answers in the test and tools were protected by confidentiality and solely used for the purpose of research. There was a one-onone discussion with the participants regarding the possible implementation of this kind of evaluation for the promotion of teachers. It was explained to them that the research was to ensure the quality of the teachers in terms of CK areas and to improve existing policies prior to the science content exam as assessment tools for educators. The participants were informed of the details of the study and assured that their identities would be kept confidential. The steps in the data gathering are illustrated in Figure 2.

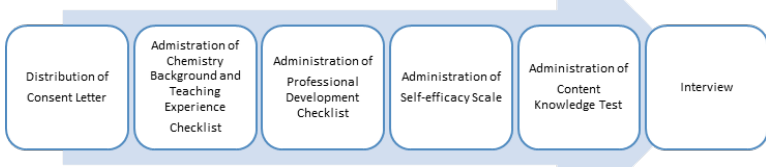

Figure 2: Steps in Data Collection.

The data was collected using both checklists and interviews. These methods gave an overview of the teacher's experiences that provided an insight into the widest possible range of opinions and views within the context. The interview was designed to validate checklists responses and to expound on the topic.

Statistical Treatment of Data. All the responses were tallied statistically using a variety of statistical tools. This was done to make the interpretation of the information gathered significant and reliable. In order to objectively quantify the answers to the questions raised in the statement of the problem in the first chapter, the researcher utilized the frequency count, percentage, weighted average, Pearson correlation and multiple regression analysis.

Frequency Count and Percentage. Frequency count and percentage were utilized to treat the data related to chemistry background, teaching experience, involvement in professional development, selfefficacy and chemistry content knowledge.

Weighted Mean. To quantitatively measure the following scores in each variables: content knowledge, involvement in professional development and selfefficacy the weighted mean was employed.

$$
\text { Mean }(\mu)=\sum \frac{X}{N}
$$

where $\Sigma=$ summation (addition) sign; $X=$ individual number; $N=$ population size.

Pearson Correlation. The relationship of the levels of content knowledge in chemistry to chemistry background, teaching experience, involvement in professional development and self-efficacy was treated using the Pearson correlation.

The following guidelines were used to quantitatively describe the relationship between variables that are involved in the study (shown in Table 9):

\section{Table 9. Interpretation of Pearson r.}

\begin{tabular}{ccc}
\hline & Coefficient, $\mathbf{r}$ & \\
\hline $\begin{array}{c}\text { Strength of } \\
\text { Association }\end{array}$ & Positive & Negative \\
\hline Small & 0.1 to 0.3 & -0.1 to -0.3 \\
\hline Medium & 0.3 to 0.5 & -0.3 to -0.5 \\
\hline Large & 0.5 to 1.0 & -0.5 to -1.0 \\
\hline
\end{tabular}

Multiple Regression Analysis. To determine how the chemistry content knowledge of teachers is influenced by chemistry background, teaching experience, involvement in professional development and selfefficacy, multiple regression analysis was employed. The regression equation explains a number of variations observable in the independent variable. It is actually the equation of a straight line in the form:

$$
y=x 1+x 2 \ldots x k
$$

where $y=$ criterion measure; $x=$ predictor. 


\section{Testing of Hypothesis for Regression Analysis.}

A small p-value (typically $\leq 0.05$ ) indicates strong evidence against the null hypothesis, the null hypothesis is rejected.

A large p-value (> 0.05) indicates weak evidence against the null hypothesis, the null hypothesis is accepted.

\section{RESULTS AND ANALYSIS}

Profile of the Respondents. The following shows the profile of the respondents in terms of their chemistry background, teaching experience, involvement in professional development and self-efficacy.

Educational Background. Educational background is one of the factors that contribute in the acquisition and development of skills and competencies of the teachers. Table 10 shows the educational attainment of the respondents.

Table 10. Distribution of Respondents as to Educational Attainment.

\begin{tabular}{lcc}
\hline Educational Attainment & F & $\%$ \\
\hline Baccalaureate degree only & 21 & 21 \\
\hline Units in Master's course & 68 & 68 \\
\hline Master's degree & 6 & 6 \\
\hline Units in Doctoral Program & 4 & 4 \\
\hline Doctoral degree & 1 & 1 \\
\hline Total & 100 & $100 \%$ \\
\hline
\end{tabular}

The data in Table 10 revealed that of the 68 respondents $(68 \%)$ who have units in master's degree, only eight acquired units in chemistry and only one (1\%) graduated with a Master's degree directly related to chemistry. Twenty-one (21) respondents (21\%) were graduates of a Baccalaureate degree. Six respondents $(6 \%)$ completed their Master's degree, 4 respondents (4\%) have doctoral units (Educational Management and Mathematics). One respondent $(1 \%)$ has completed a doctoral degree major in Educational Management.

The teacher-respondents were mostly enrolled in graduate school and have earned units for their Master's degree. Based on the interview, most of the teachers who were over 40 years old and above had no interest in pursuing their career to the next level. They did not see anymore the benefit that they could get from it. One of them even mentioned that she already attained the peak of her career as a teacher.

During the interview of teachers, head teachers, and principal, two (2) of the interviewees suggested that teachers must pursue further studies to be able to improve one's science CK. A master's degree or at least 18 units in the master's program is one of the qualifications to be able to be promoted to a higher position.

\section{Table 11. Distribution of Respondents according to Baccalaureate Degree.}

\begin{tabular}{lcc}
\hline Baccalaureate Degree & F & \% \\
\hline BSED major in Biological Science & 5 & 5 \\
\hline BSED major in Biology & 24 & 24 \\
\hline BSED major in Chemistry & 12 & 12 \\
\hline BSED major in General Science & 34 & 34 \\
\hline BSED major in Physical Science & 5 & 5 \\
\hline BSED major in Physics & 8 & 8 \\
\hline Other course related to Biology & 1 & 1 \\
\hline $\begin{array}{l}\text { Other course related to General Science } \\
\text { (e.g BSED major in Science) }\end{array}$ & 1 & 1 \\
\hline $\begin{array}{l}\text { Other course related to Natural Science } \\
\text { (e.g BSED major in Natural Science } \\
\text { and BS Natural Science) }\end{array}$ & 2 & 2 \\
\hline $\begin{array}{l}\text { Other courses (e.g BS Nursing and BS } \\
\text { Geology) }\end{array}$ & 2 & $\mathbf{1 0 0}$ \\
\hline $\begin{array}{l}\text { Other courses related to Chemistry (e.g. } \\
\text { BS Chemistry, Industrial Chemistry, } \\
\text { and BS Chemical Engineering) }\end{array}$ & 6 & 6 \\
\hline \begin{tabular}{l} 
Total \\
\hline
\end{tabular} & $\mathbf{1 0 0}$ & \\
\hline
\end{tabular}

Table 11 shows that most of the respondents have a baccalaureate degree in BSED major in General Science. This implies that there are very few teachers who have specialization in teaching Chemistry. The sample showed that many teachers specialize in biology rather than chemistry, physics and natural science. There is an unequal proportion of teachers when it comes to specialization or expertise.

Table 12 shows that few teachers focus on getting a master's degree specializing in only one subject matter like biology, chemistry, and physics. This implies that, science teachers want to have a wide range of knowledge in various areas of science. Some of the teachers were specializing in educational management and educational administration. These specializations are instrumental for a teacher to be promoted as Head Teacher or Master Teacher.

Very few have shown interest in pursuing a doctoral degree. Only $4 \%$ of the respondents have earned doctoral units. Two out of 4 respondents have credit units in Doctor of Education major in Educational Management. While only $25 \%$ is pursuing a Doctor of Philosophy in Science Education; 1 out of 4 respondents had units in Doctor of Philosophy major in Mathematics (shown on Table 13). 
Table 12. Distribution of Respondents with Units in Master's Degree.

\begin{tabular}{lcc}
\hline Master's Degree & F & $\%$ \\
\hline $\begin{array}{l}\text { MA in Education major in Biological } \\
\text { Science }\end{array}$ & 2 & 2.94 \\
\hline MA in Education major in Biology & 5 & 7.35 \\
\hline MA in Education major in Chemistry & 7 & 10.29 \\
\hline $\begin{array}{l}\text { MA in Education major in } \\
\text { Developmental Education }\end{array}$ & 1 & 1.47 \\
\hline $\begin{array}{l}\text { MA in Education major in Educational } \\
\text { Administration }\end{array}$ & 2 & 2.94 \\
\hline MA in Education major in Educational & 1 & 1.47 \\
Management & & \\
\hline MA in Education major in Natural & 10 & 14.71 \\
Science & & \\
\hline MA in Education major in Physics & 6 & 8.82 \\
\hline MA in Education major in Science & 18 & 26.47 \\
Education & & 1.47 \\
\hline MS in Chemistry & 1 & $\mathbf{1 0 0}$ \\
\hline MS in General Science & 2 & 2.94 \\
\hline MS in Physics & 2 & 2.94 \\
\hline MS in Science Education & $\mathbf{6 8}$ & \\
\hline Total & & \\
\hline
\end{tabular}

Table 13. Distribution of Respondents with Units in Doctoral Units.

\begin{tabular}{lll}
\hline Doctorate Degree & F & \% \\
\hline $\begin{array}{l}\text { Doctor of Education major in } \\
\text { Educational Management }\end{array}$ & 2 & 50 \\
\hline $\begin{array}{l}\text { Doctor of Philosophy in Science } \\
\text { Education }\end{array}$ & 1 & 25 \\
\hline $\begin{array}{l}\text { Doctor of Philosophy major in } \\
\text { Mathematics }\end{array}$ & 1 & 25 \\
\hline Total & $\mathbf{4}$ & $\mathbf{1 0 0}$ \\
\hline
\end{tabular}

Chemistry Background. A checklist (Appendix D) was developed and provided a basis for measuring the chemistry background of respondents. The highest score for chemistry background is 150 points. Table 14, shows the scores obtained in the chemistry background. The equivalent points were all based on the number of earned units in Chemistry.

Table 14. Scores in Chemistry Background.

\begin{tabular}{llcc}
\hline Score range & Interpretation & $\mathbf{F}$ & \% \\
\hline $1-30$ & Very Low & 80 & 80 \\
\hline $31-60$ & Low & 12 & 12 \\
\hline $61-90$ & Moderate & 1 & 1 \\
\hline $91-120$ & High & 7 & 7 \\
\hline $121-150$ & Very High & 0 & 0 \\
\hline Total & & $\mathbf{1 0 0}$ & $\mathbf{1 0 0}$ \\
\hline
\end{tabular}

The table shows that $80 \%$ of the respondents have very low chemistry background, and only $7 \%$ of the respondents have the high chemistry background. These results imply that most teacher-respondents do not have adequate chemistry background, their undergraduate, master, and doctoral degrees are not aligned with chemistry. This finding is supported by the data on Tables 11, 12, and 13 .

Teaching Experience. TE refers to the teachers' number of years in teaching. Table 15 shows the data about the number of years in teaching.

Table 15. Distribution of Respondents in terms of Teaching Experience.

\begin{tabular}{lccl}
\hline Score & $\mathbf{F}$ & $\mathbf{\%}$ & Interpretation \\
\hline 10 & 7 & 7 & Junior \\
\hline 20 & 20 & 20 & Senior \\
\hline 30 & 13 & 13 & Master Teacher 1 \\
\hline 40 & 9 & 9 & Master Teacher 2 \\
\hline 50 & 51 & 51 & Master Teacher 3 \\
\hline Total & $\mathbf{1 0 0}$ & $\mathbf{1 0 0} \%$ & \\
\hline
\end{tabular}

Table 15 shows that 51 respondents had the score of 50 , which meant that the teacher served for 21 years or more while 7 respondents had the score of 10 , which meant that the teacher, had an experience in teaching for less than 5 years (junior). More than half of the sample were master teachers. It is a positive indication because nowadays there are still some teachers who leave their profession and transfer to other jobs because of the difficult demands of the teaching job.

Suggestion: This finding indicates that many teachers decide to stay in the profession despite the challenges of the job. They affirmed they enjoyed their work and almost half of their lives have been spent in teaching. Although there were some teachers who have been serving their respective schools for several years, it was observed that many of the respondents were young teachers. Based on the interview and observation, these young breed of teachers were very competitive and highly committed to the teaching profession. Some of them, aspire to be promoted to a higher position such as Teacher II and even Teacher III.

Professional Development. This variable measured the frequency of teachers' involvement in professional development activities within the past 12 months.

Table 16 indicates that the respondents received insufficient training from the government and hardly participated in the different professional 
Table 16. Scores in Professional Development Checklist.

\begin{tabular}{llcc}
\hline Score range & Interpretation & $\mathbf{F}$ & \% \\
\hline $1-19$ & Very Low & 33 & 33 \\
\hline $20-38$ & Low & 33 & 33 \\
\hline $39-57$ & High & 20 & 20 \\
\hline $58-76$ & Very High & 14 & 14 \\
\hline $\boldsymbol{N}$ & & $\mathbf{1 0 0}$ & $\mathbf{1 0 0}$ \\
\hline
\end{tabular}

development activities. From the one-on-one interview, $100 \%$ or 10 out of 10 teacher participants said that they received only two weeks of training for their teaching for the entire school year. Some teachers expressed their difficulties in teaching the K-12 curriculum. A respondent said that it was a struggle to explore another field of science because it was outside her specialization. This presents a potential problem related to the quality of teaching. In many studies, professional development activities like attending training, seminars, conferences, and workshops have significantly increased teacher's content knowledge in Science. Even increasing the number of hours in attending professional development activities resulted in a significant increase in the content knowledge of teachers.

Ten (10) of the interviewees or $50 \%$ said that science content knowledge of in-service teachers can be improved by attending training, seminars, workshop and other professional development. Two among the interviewees suggested that teachers must be given more in-depth training. They must be given a longer training focusing more on the topics they have difficulties with. Some, also mentioned that subject matter experts must conduct the training.

Self-efficacy. The SE Scale was used in this study. The scale is a measure consisting of thirteen (13) items, which were answerable using a 4-point scale. This scale was designed to assess SE in order to gain understanding the difficulties teachers encounter in their school activities.

As revealed in Table 17, seventy-four (74\%) have very high SE and only three (3) rated themselves low. Although some of the teachers rated themselves highly positive on SE, some teachers have low chemistry $\mathrm{CK}$. One teacher who had a score of 15 in the $\mathrm{CK}$ test rated herself positively (52). The teacher with the highest CK score got a SE rating of 47. The limitation of this study is that the data were based on a self-report instrument. Responses in the self-efficacy instrument were not directly observed. It is assumed that the teachers answered the scale with utmost honesty.
Table 17. Scores on Self-efficacy Scale.

\begin{tabular}{llcc}
\hline Score range & Interpretation & $\mathbf{F}$ & $\mathbf{\%}$ \\
\hline $1-13$ & Very Low & 0 & 0 \\
\hline $14-26$ & Low & 3 & 3 \\
\hline $27-39$ & High & 23 & 23 \\
\hline $40-52$ & Very High & 74 & 74 \\
\hline Total & & $\mathbf{1 0 0}$ & $\mathbf{1 0 0}$ \\
\hline
\end{tabular}

Chemistry Content Knowledge. Data in Tables 18 $\mathrm{A}$ and $\mathrm{B}$ present the scores that describe the level of CK of teachers in Chemistry.

\section{Table 18 A. Distribution of Chemistry Content Knowledge Score of Respondent.}

\begin{tabular}{|c|c|c|c|}
\hline Score Range & F & $\%$ & $\begin{array}{l}\text { Descriptive } \\
\text { Interpretation }\end{array}$ \\
\hline $55-60$ & 0 & 0 & Advanced \\
\hline $49-54$ & 2 & 2 & Proficient \\
\hline $43-48$ & 20 & 20 & $\begin{array}{c}\text { Approaching } \\
\text { Proficient }\end{array}$ \\
\hline $37-42$ & 13 & 13 & Developing \\
\hline 36 and below & 65 & 65 & Beginning \\
\hline Total & 100 & 100 & \\
\hline Mean & & & Beginning \\
\hline
\end{tabular}

Table 18 A shows that sixty-five respondents scored between 36 and below. The level of Chemistry CK of most teachers was low eventhough $18 \%$ of sample population have a Baccalaureate degree specializing in Chemistry and $68 \%$ of that population have units in master's program. The total mean of the score of the chemistry CK was 31.74 . On the average, the teachers were in the beginning level only. More than a majority of the science teachers had insufficient knowledge in Chemistry, despite their possession of an appropriate baccalaureate degree and even units in higher education. Twenty (20\%) of the respondents were approaching proficiency while only $2 \%$ was proficient in the test that determined the level of CK in Chemistry.

During the examination, most teachers said that the test was difficult. However, most of them submitted the answer sheet before the time. Most of them did not complete answering the short response questions. It can be surmised from their actions that they did not know the answer to some questions, so they skipped the items and left them blank. One Physics teacher mentioned that she did not know much about chemical bonding and other higher chemistry concepts. 
The chemistry CK test was used to assess the level of CK of teacher-respondents. This test was aligned with the $\mathrm{K}$ to 12 science curriculum, covering thirteen (13) content areas in chemistry. Generally, only $56 \%$ of the questions were answered correctly by the teachers-respondents. The teachers had insufficient knowledge in chemistry, despite their possession of a good baccalaureate degree, units in higher education, lengthy teaching experience and participation in yearly teacher's training. Science $\mathrm{CK}$, as well as in-depth understanding of chemistry concepts aligned to the $\mathrm{K}$ to 12 curricula are necessary for teachers to make connections across different science subjects. Since one of the main focus of the $\mathrm{K}$ to 12 curricula is the concept and skill in Chemistry, there is a great need for mastery and in-depth understanding of chemistry topics. Therefore, if there is insufficiency in the teacher's chemistry $\mathrm{CK}$, the integration across science topics and other disciplines will be impossible.

The result of the teacher's chemistry CK test was also similar with the result of the study of Kind (2014). Kind found out that some teachers who were academically able novice teachers held some misconceptions of basic chemical concepts. This finding was also supported by the study of Lloyd et.al (1998), Schoon \& Boone (1998) and Lin et.al (2000) which found that educators have held misconceptions on chemistry concepts, despite their possession of a good baccalaureate degree, extensive professional development, and lengthy experience in the academe.

The main instrument in the data gathering was the test in Chemistry CK. This was able to assess the level of chemistry CK of teachers aligned to the $\mathrm{K}$ to 12 science curriculum. The test was composed of multiple and short-response questions. Diamond and coworkers (2014) used multiple measures to examine science content knowledge of elementary school teachers, self-reported science knowledge, teacher science knowledge test, class observations and college science courses taken. CK had a significant effect on student science achievement outcomes. The teachers' self-reported science knowledge and college science courses taken did not predict student science achievement nor improvements in student learning (Diamond 2014).

Table $18 \mathrm{~B}$ shows the percentage of correct answers per concept area by the respondents as shown in the content knowledge test. The data shows that the least mastered content areas in chemistry were Biomolecules (34\%), Metals and Non-Metals (36.5\%), Matter and Its Properties (43.2\%), Periodic Table of Elements (45\%) and Particle Nature of Matter (52.25\%). Biomolecules is a topic in Grade
10, Metals and Non-Metals is a topic for discussion in Grade 7, and Matter and Its properties, Particle Nature of Matter and Periodic Table of Elements are topics for Grade 8. Since all the respondents collectively scored below $75 \%$ in all topics in Chemistry from Grades 7-10, it can be deduced that the science teachers lacked expertise and mastery of the subject matter. This supports the discussion on Table $18 \mathrm{~A}$, emphasizing that respondents were only at the beginners level, very much like the students they were teaching.

Table 18 B. Percentage of Correct Answer in the Chemistry Content Knowledge per Concept Area.

\begin{tabular}{lll}
\hline Grade Level & Chemistry Concept Area & $\%$ \\
\hline Grade 7 & Substances and Mixtures & 65.33 \\
\cline { 2 - 3 } & Elements and Compounds & 61.00 \\
\cline { 2 - 3 } & Acid and Bases & 69.60 \\
\cline { 2 - 3 } & Metals and Non-metals & 36.50 \\
\hline Grade 8 & Matter and its properties & 43.20 \\
\cline { 2 - 3 } & Atomic Structure & 69.33 \\
\cline { 2 - 3 } & Particle Nature of Matter & 52.25 \\
\cline { 2 - 3 } & Periodic Table of Elements & 45.00 \\
\hline \multirow{2}{*}{ Grade 9 } & Chemical bonding & 56.75 \\
\cline { 2 - 3 } & Organic Compound & 51.5 \\
\hline \multirow{2}{*}{ Grade 10 } & Gas laws & 58.14 \\
\cline { 2 - 3 } & Chemical Reactions & 34.00 \\
\cline { 2 - 3 } & Biomolecules & \\
\hline
\end{tabular}

Table 19 shows that on average, a teacher respondent had no answer to 11 questions most especially on the short-response items. It may indicate two things; first the respondents did not know the answer, and second, they were too lazy to write a short explanation to their answer. Question number 49 was the one that was most left unanswered by the respondents.

Correlation between CK and Other Variables. The results of the Pearson Correlations between Chemistry $\mathrm{CK}$ and the other variables such as $\mathrm{CB}$, TE, involvement in PD and SE are presented in Table 20.

The correlation between Chemistry CK and TE $(\mathrm{r}=0.11)$, Chemistry CK and PD $(\mathrm{r}=0.54)$, CCK and SE $(r=0.51)$ and Chemistry CK and TE $(r=0.11)$, CCK and CB ( $r=0.19)$ were statistically significant.

It can be noted that the association between CK in chemistry and chemistry background is small. This may be attributed to the non-alignment or nonspecialization of the baccalaureate to master's and doctoral degree the respondents have obtained. The 
Table 19. Frequency of Item Number with No Answer.

\begin{tabular}{|c|c|c|c|c|c|}
\hline $\begin{array}{l}\text { Item } \\
\text { No. }\end{array}$ & f & $\%$ & $\begin{array}{c}\text { Item } \\
\text { No. }\end{array}$ & f & $\%$ \\
\hline 1 & 4 & 4 & 27 & 7 & 7 \\
\hline 2 & 0 & 0 & 28 & 4 & 4 \\
\hline 3 & 2 & 2 & 29 & 6 & 6 \\
\hline 4 & 7 & 7 & 30 & 8 & 8 \\
\hline 5 & 4 & 4 & 31 & 5 & 5 \\
\hline 6 & 8 & 8 & 32 & 9 & 9 \\
\hline 7 & 2 & 2 & 33 & 5 & 5 \\
\hline 8 & 3 & 3 & 34 & 4 & 4 \\
\hline 9 & 11 & 11 & 35 & 5 & 5 \\
\hline 10 & 4 & 4 & 36 & 9 & 9 \\
\hline 11 & 3 & 3 & 37 & 6 & 6 \\
\hline 12 & 6 & 6 & 38 & 5 & 5 \\
\hline 13 & 9 & 9 & 39 & 6 & 6 \\
\hline 14 & 6 & 6 & 40 & 13 & 13 \\
\hline 15 & 7 & 7 & 41 & 5 & 5 \\
\hline 16 & 3 & 3 & 42 & 7 & 7 \\
\hline 17 & 3 & 3 & 43 & 28 & 28 \\
\hline 18 & 3 & 3 & 44 & 33 & 33 \\
\hline 19 & 9 & 9 & 45 & 31 & 31 \\
\hline 20 & 13 & 13 & 46 & 30 & 30 \\
\hline 21 & 6 & 6 & 47 & 37 & 37 \\
\hline 22 & 8 & 8 & 48 & 32 & 32 \\
\hline 23 & 7 & 7 & 49 & 55 & 55 \\
\hline 24 & 5 & 5 & 50 & 46 & 46 \\
\hline 25 & 4 & 4 & 51 & 38 & 38 \\
\hline 26 & 5 & 5 & Mean & 11.29 & \\
\hline
\end{tabular}

correlation between teaching experience and CK in chemistry is likewise small. The finding indicates that the number of years in teaching does not equate to becoming a content expert in a specific field. Though majority of the respondents were master teachers, the rank does not make them adept with content. The large association between CK in chemistry and professional development indicates that increasing involvement in PD activities may lead to higher CK. Finally, the large link between self-efficacy and CK in chemistry shows that the strengthening or increasing teacher's self-efficacy may also result to higher CK in chemistry.

These results indicate that the increase in Chemistry $\mathrm{CK}$ was related to the increase in the TE of the teachers. The increase in the Chemistry CK score was also related to the increasing teachers' SE. Additionally, the increase in teachers' chemistry CK was related to the increasing frequency and duration of teachers' involvement in PD activities. Teachers' $\mathrm{CB}$ were positively correlated to Chemistry CK
Table 20. Pearson Correlation of CK in Chemistry to Selected Variables

\begin{tabular}{lcll}
\hline Variables & r & $\begin{array}{l}\text { Strength of } \\
\text { Association }\end{array}$ & Relation \\
\hline $\begin{array}{l}\text { Chemistry } \\
\text { Background }\end{array}$ & 0.19 & Small Positive & $\begin{array}{l}\text { Significant } \\
\text { Correlation }\end{array}$ \\
\hline $\begin{array}{l}\text { Teaching } \\
\text { Experience }\end{array}$ & 0.11 & Small Positive & $\begin{array}{l}\text { Significant } \\
\text { Correlation }\end{array}$ \\
\hline $\begin{array}{l}\text { Professional } \\
\text { Development }\end{array}$ & 0.54 & Large Positive & $\begin{array}{l}\text { Significant } \\
\text { Correlation }\end{array}$ \\
\hline Self-efficacy & 0.51 & Large Positive & $\begin{array}{l}\text { Significant } \\
\text { Correlation }\end{array}$ \\
\hline
\end{tabular}

score. Very few teachers who have qualifications aligned to Chemistry obtained a higher Chemistry CK score. It was noted that the small correlation may be due to non-alignment or non-specialization of the baccalaureate to master's and doctorate degree the respondents have obtained.

\section{Effects of Selected Variables to on CK in Chemistry.}

The multiple regression analysis was used to identify which among the independent variable greatly affect the teachers' level of CK in Chemistry. The result of the Multiple Regression Analysis is presented in Table 16.

The regression equation is

Chemistry CK $=0.07 \mathrm{CB}+1.11 \mathrm{TE}+0.24 \mathrm{PD}+0.64 \mathrm{SE}$

Table 21. Effects of Selected Variables to Teachers' CK in Chemistry.

\begin{tabular}{lccccc}
\hline & Coefficients & $\begin{array}{c}\text { Standard } \\
\text { Error }\end{array}$ & t Stat & P-value & Decision \\
\hline Intercept & -10.82 & 6.44 & -1.68 & 0.10 & \\
\hline $\begin{array}{l}\text { Self- } \\
\text { Efficacy }\end{array}$ & 0.64 & 0.14 & 4.71 & 0.00 & Reject $\mathrm{H}_{0}$ \\
\hline $\begin{array}{l}\text { Professional } \\
\text { Development }\end{array}$ & 0.24 & 0.05 & 5.30 & 0.00 & Reject $\mathrm{H}_{0}$ \\
\hline $\begin{array}{l}\text { Teaching } \\
\text { Experience }\end{array}$ & 0.11 & 0.06 & 1.90 & 0.06 & Accept $\mathrm{H}_{0}$ \\
\hline $\begin{array}{l}\text { Chemistry } \\
\text { Background }\end{array}$ & 0.07 & 0.04 & 1.98 & 0.05 & Reject $\mathrm{H}_{0}$ \\
\hline
\end{tabular}

Table 21 shows that $\mathrm{CB}, \mathrm{SE}$, and PD have a p-value less than or equal to 0.05 . This indicates that the null hypothesis must be rejected, therefore the predictors (CB, PD, and SE) have a linear relation to variable $y$ (Chemistry CK). From the result of this analysis, one can conclude that the more involvement of a teacher to a PD activity, the more she/he increases one's CK. Additionally, SE among teachers must also be enhanced because the regression analysis found a relation between Chemistry CK and SE. Results indicate that involvement in PD activities and SE have greatly affected the CK of teachers. Chemistry 
CK of teachers was greatly influenced by the $\mathrm{CB}$ of teachers. The more a teacher acquired units related to chemistry, the more he/ she increased chemistry CK. However, the TE had no effect to Chemistry CK. Hence, the null hypothesis was accepted.

Implications Drawn toward the Development of a National Promotional Examination. Promotion is very important in the life of a professional teacher. Promotion may indicate growth and development among professionals. That growth may be in terms of knowledge, skills and social interaction. During the interview of teachers, head teachers and principals, $70 \%$ or 14 out 20 said that promotion was very important. There are two main reasons why promotion was important to them. It (1) indicates growth and development and (2) it assures their financial stability. Others mentioned that promotion is important because it serves as their achievement, self-worth and boosts their self-esteem.

DepEd Order No. 66, s.2007, states that to further achievement, significant revisions were adopted in the following: (1) the principles of merit and fitness, (2) objectivity and (3) uniformity in evaluation; and (4) strengthening of the selection process for other teaching, related teaching and non-teaching personnel in the Department. This DepEd order serves as a guideline on teacher appointment and promotion of Teacher II and III, and other teaching and related teaching group with the exception of School heads - Principals and Head Teachers and all Non-Teaching Groups.

The Personnel Selection Board/Committee (PSB/C) evaluates the candidates for promotion using the criteria as the indicator and conduct further assessment such as written examination, skills tests, interview and others of qualified candidates. Those criteria should be uniformly applied and implemented for all promotions in the Central, Region and Division offices (shown in Table 17). The minimum requirement for teacher appointment and promotion are the following: (1) the Performance rating of the candidates for the last three (3) rating periods prior to screening should be at least Very Satisfactory, (2) the experience of the teacher must be relevant to the duties and functions of the position to be filled, (3) have outstanding accomplishments, (4) have completed Academic Requirements for Master's Degree, Master's Degree, completed academic Requirements for Doctoral Degree or Doctoral Degree, (5) participant must have specialized training (e.g Scholarship Programs, Short Courses, Study Grants) - three (3) or more training activities in District, Division, and Regional level, and (6) requires candidates/appointees to undergo Psychological tests. The PSB/C shall also determine the potentials of the candidate based on the components. These components include Communication skills (speaks and writes effectively in Filipino and English), ability to present ideas, alertness, judgment and leadership abilities. Additionally, Psychosocial attributes and personality traits are also determined based on the following factors: human relations, stress tolerance, and decisiveness.

Table 22. Criteria for Promotion and the Equivalent Points

\begin{tabular}{lc}
\hline Criteria & Points \\
\hline Performance & 35 \\
\hline Experience & 5 \\
\hline Outstanding Accomplishments & 20 \\
\hline Education & 25 \\
\hline Training & 5 \\
\hline Psycho-social attributes & 5 \\
\hline Potential & 5 \\
\hline TOTAL & $\mathbf{1 0 0}$ \\
\hline
\end{tabular}

From Table 22, the criteria that have the largest points are the teacher's performance rating and education. There is no test which measures CK in the requirements for promotion and appointment of teachers. This is a potential concern because it can be simply assumed that teachers can be promoted from one position to the other without the guarantee of strong CK. Therefore, there is a necessity to include $\mathrm{CK}$ in one of the promotion criteria of teachers. This will assure the quality of the teachers in terms of Chemistry CK.

In the interview, twenty (20\%) said that the current criteria for promotion were not objective and fair. One reason mentioned by a teacher was favoritism. According to her, if you were not close to your superior, you were not promoted. One head teacher mentioned that the criteria were not fair because it requires too much from the teacher. She cited educational attainment. If the teacher, could not send herself to graduate school, she remains as Teacher I, unless she reaches 20 years of teaching. Additionally, another head teacher revealed that although the criteria were objective, evaluators have their perception/own bias on how to grade a teacher. A teacher participant revealed that in some Divisions, the criteria were not followed. She also revealed that, even if a teacher was qualified for the job, someone may want to hinder her/him from obtaining that position. She strongly suggested that there should be a cleansing in the system. The "palakasan" system is still strongly practiced in the academe. A teacher even cited "Its whom you know, not what you know, to get hired 
and promoted to the next rank". Another respondent mentioned that in the examination given by the Division of City Schools, she ranked third but it took her two years to get hired, whereas, an examinee who ranked 12th in the list was immediately absorbed in a school she had not named.

With this information revealed by respondents, it may be appropriate to include a qualifying examination which not only measures pedagogical knowledge but content as well. This comprehensive examination for promotion must be wide spectrum to cover all areas of learning/teaching in science.

It is recommended that there be two separate tracks for teachers' promotion, one is aligned to classroom teaching while the other is for administrative work. The respondent's educational attainment must be utilized to place them on the right track. Teachers whose major in the Masters and Ph.D. programs are related to administration, supervision, management and/or leadership must be promoted as administrators who will be placed to run departments and offices. Teachers whose baccalaureate, masters and doctorate degrees are aligned to Chemistry must be promoted as master teachers or experts, who will be placed on teaching and at the same time mentors of novice teachers.

Based on the results and findings of this study, a new research paradigm was made. Figure 3 shows the relationship of $\mathrm{CB}, \mathrm{SE}$ and involvement in

PD to Chemistry CK. The three (3) variables greatly affect the increase in the score in the Chemistry CK test which is the basis for a proposed National Promotional Examination for Public school Science Teachers. The National Promotional Examination, on the other hand, forces teachers to improve their CK.

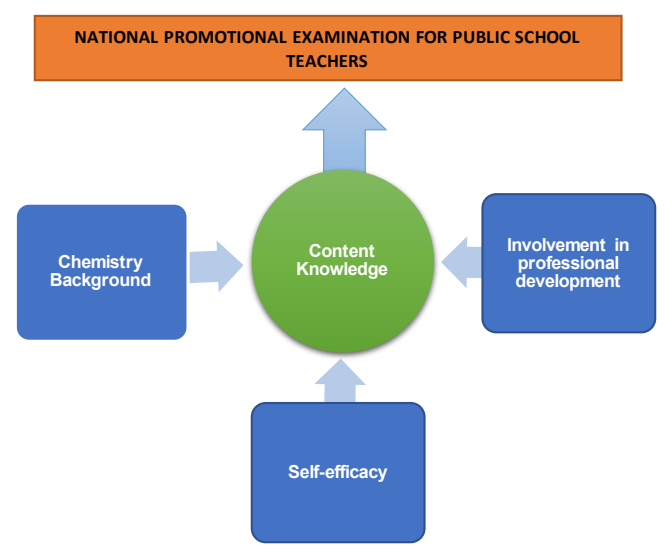

Figure 3 shows that $C B, S E$ and $P D$ are predictors of $C K$ in chemistry. This framewok may serve as basis for a proposed National Promotional Examination for Public School Science Teachers

\section{CONCLUSIONS}

In the light of the findings of the study, the following conclusions are hereby derived:

The majority of science teachers handling grades 7-10 have a low level of CK in Chemistry. Despite their possession of a degree, units in Master's, and substantial teaching experience, they are likely considered as beginners only, not content experts.

The variables such as TE, $\mathrm{PD}, \mathrm{CB}$, and $\mathrm{SE}$ are significantly correlated to the $\mathrm{CK}$ of teachers in chemistry. Teachers' PD and SE exert the strongest influence in the development of CK of teachers in Chemistry. The CB exerts a weak influence on the upliftment of chemistry CK among teachers. The TE of a teacher does not influence teacher's CK in chemistry.

\section{RECOMMENDATIONS}

Based on the viable findings of this research work, the following recommendations are made:

Schools must provide a more in-depth training, focusing on both content and pedagogy. More frequent and longer PD activities must be given to teachers since it is proven that it will greatly affect their CK in science.

Training of teachers should be done with the guidance of experts not only in Chemistry but also in other subject areas. This will assure accuracy of the CK and skills during training.

The criteria for teacher promotion should be revisited and establishing two tracks, administrative and teaching track should be considered.

The criteria for promotion and appointment of a teacher must include examination for CK for teachers. Since promotion indicates professional growth and development, one must be promoted if there is a growth in terms of content and pedagogical knowledge.

Furthermore, it is recommended that a body or independent committee be created to draft a national promotional examination for teachers handling junior and senior classes.

\section{ACKNOWLEDGEMENT}

The authors would like to extend their gratitude to the Department of Science and Technology-Science Education Institute (DOST-SEI) headed by Dr. Josette T. Biyo for the research grant and support. 
JDG acknowledges the DOST-SEI National Consortium in Graduate Science and Mathematics Education (NCGSME) for the scholarship grant. AMG is grateful for support from the Doña Salustiana Dee Foundation.

\section{REFERENCES}

Alcober N. Briones admits challenges to K-to-12. The Manila Times [Internet]. 2017 Jan 14 [cited 2017 April 18]; Available from: https://www.manilatimes. net/briones-admits-challenges-k-12/306898/

Aquino G. Educational Management: Principles, Functions, and Concepts. Quezon City: Rex Printing Company, Inc; 2000.

Arzi H, White R. Change in teachers' knowledge of subject matter: A 17-year longitudinal study. Wiley InterScience. 2007; 92(2): 21-251. doi: 10.1002/ sce. 20239

Bandura A. Self-Efficacy: The Exercise of Control. New York: W.H. Freeman; 1997. Chapter 3, Selfefficacy; p. 79-113.

Banilower ER, Heck DJ, Weiss IR. Can professional development make the vision of the standards a reality? The impact of the national science foundation's local systemic change through teacher enhancement initiative. Journal of Research in Science Teaching. 2007; 44(3): 375-395. doi: 10.1002/tea.20145.

Bilbao P, Lucido P, Iringan T, Javier R. Curriculum Development. Quezon City: Lorimar Publication; 2008.

Bradley JD, Mosimege MD. Misconceptions in acids and bases: A comparative study of student teachers with different chemistry backgrounds. South African Journal of Chemistry. 1998; 51(3): 137-145.

Calmorin L, Calmorin M. Methods of Research and Thesis Writing. 2nd ed. Quezon City: Rex Printing Company, Inc.; 2012.

Chua QNL. Preparing teachers for the big reform. Philippine Daily Inquirer [Internet]. 2012 April 1 [cited 2017 March 24]; Available from: http:// newsinfo.inquirer.net/170691/preparing-teachersfor-the-big-reform

Coll R, Taylor N. Alternative conceptions of chemical bonding held by upper secondary and tertiary students. Research in Science \& Technological Education. 2001; 19(2):171-191.
Darling-Hammond L. America's commitment to equity will determine our future. The Phi Delta Kappan. 2010; 91: 8-14.

De Jong O, Acampo J, Verdock A. Problems in teaching the topic of redox reactions: Actions and conceptions of chemistry teachers. Journal of Research in Science Teaching. 1995; 32(10): 0971110 .

Diamond B, Maerten-Rivera J, Rohrer R, Lee O. Effectiveness of a Curricular and Professional Development Intervention at Improving Elementary Teachers' Science Content Knowledge and Student Achievement Outcomes: Year 1 Results. Journal of Research in Science Teaching. 2014; 51(5): 635658.

Faustino P. Pinoy Magsaysay awardees oppose 12year basic education cycle. GMA News online [Internet]. 2010 Aug 28 [cited 2017 Feb]; Available from: https://www.gmanetwork.com/news/news/ nation/199615/pinoy-magsaysay-awardees-oppose12-year-basic-education-cycle/story/

Fleer M. Supporting scientific conceptual consciousness or learning in 'a roundabout way' in playbased contexts. International Journal of Science Education. 2009; 31(8):1069-1089. Doi $10.1080 / 09500690801953161$.

Gabel DL, Samuel KV, Hunn D. Understanding the particulate nature of matter. Journal of Chemical Education. 1987: 64: 695-697.

Gay LR, Airasian P. Educational Research: Competencies for analysis and applications. 7th ed. New Jersey: Person Education, Inc.; 2003.

Geddis AN, Onslow B, Beynon C, Oesch J.Transforming content knowledge: Learning to teach about isotopes. Science Education. 1993; 77(6): 575-591.

Geronimo J. Many schools not yet training teachers for $\mathrm{K}$ to 12. Rappler [Internet]. 2015, April 14 [cited 2017 Jan 23]; Available from http://www. rappler.com/nation/89892-pia-cayetano-trainingteachers-k12.

Gibson S, Dembo MH. Teacher Efficacy: A construct validation. Journal of Educational Psychology. 1984; 76: 569-582.

Heller JI, Daeler KR, Wong N, Shinohara M, Miratrix LW. Differential effects of three professional development models on teacher knowledge and students achievement in elementary science. Journal 
of Research in Science Teaching. 2010; 49(3):333362. doi:10.1002/tea.21004.

Hill H, Ball DL. The curiuos-and crucial-case of mathematical knowledge for teaching. The Phi Delta Kappan. 2009; 91: 68-71.

Johnson H, Cotterman M. Developing Pre-service Teachers' Knowledge of Science Teaching Through Video Clubs. Journal Science Teacher Education. 2015; 26:393-417.

Kaya ON. The nature of relationships among the components of pedagogical content knowledge of pre-service science teachers: 'ozone layer depletion' as an example. International Journal of Science Education. 2009; 31(7): 961-988. doi: $10.1080 / 0950069080911326$

Kind V. A Degree Is Not Enough: A quantitative study of aspects of pre-service science teachers' chemistry content knowledge. International Journal of Science Education. 2014; 36(8):1313-1345. doi. 10.1080/09500693.2013.860497

Kruse RA, Roehrig GH. A comparison study: Assessing teachers' conceptions with the chemistry concepts inventory. Journal of Chemical Education. 2005; 82:1246-1250.

Lekhu M. Relationship between Self-efficacy Beliefs of Science Teachers and Their Confidence in Content Knowledge. Journal of Psychology. 2013; 23(1):109-112.

Lin $\mathrm{H}$, Cheng $\mathrm{H}$, Lawrenz $\mathrm{F}$. The assessment of students' and teachers' understanding of gas laws. Journal of Science and Mathematics Education in South-East Asia. 2000; 23(2):22-35.

Lloyd JK, Smith RG, Fay CL, Khang GN, Kam Wah LL, Sai Cl. Subject knowledge for teaching at primary level: A comparison of pre-service teacher in England and Singapore. International Journal of Science Education. 1998; 20:521-532.

Lucille LKW. Understanding the particulate nature of matter on water: Pre-service elementary school science teachers' views. Journal of Science and Mathematics Education in S.E Asia. 2000;23(2):5872.

Macario N, Aquino G. Administration and supervision for Philippine Schools. Quezon City: Phoenix Publishing House, Inc.; 1967.

Macdonald D, Hoban G. Science Content Knowledge Gained through the Use of Slowmation.
The International Journal of Learning. 2009;16:6. Available from http://www.Learning-Journal.com

McConnell TJ, Eberhardt J, Parker JM. Assessing Teachers' Content Knowledge: A Strategy for Assessing Depth of Understanding. Journal Science Education. 2013; 24(4):717-743.

Montenegro C. On World Teachers Day, DepEd bares $\mathrm{K}+12$ by 2012.GMA news Online [Internet]. 2010 Oct 5 [cited 2016 Dec 10] Retrieved from: https://www.gmanetwork.com/news/news/ nation/202666/on-world-teachers-day-depedbares-k-12-by-2012/story/

Napolcom / PNP Entrance \& Promotional Examination Coverage [Internet]. 2017 Feb 10 [cited 2017 Mar 8]. Available from: http:// philboardresults.com/2017/02/examinationcoverage-napolcom-pnp-entrance-promotionalexams/

Nicavera E. DepEd works to end K-12 woes in Negros Island Region. Sunstar [Internet]. 2017 April 5 [cited 2017 April 18]; Available from: https://www.sunstar.com.ph/article/135259

Parreno E, Jimenez R. Basic statistics: A Worktext. 2nd ed. Quezon City: C \& E Publications; 2014.

Powell-Moman A, Brown-Schlid V. The Influence of a two-year Professional Development institute on teacher Self-efficacy and use of inquiry-based instruction. Science Educator. 2011; 20(2): 47-53.

Roth WM. The particulate theory of matter for pre-service elementary teachers. Journal of Science Teacher Education. 1992; 3: 115-122.

Santau A, Maerten-Rivera J, Bovis S, Orend J. A Mile Wide or an Inch Deep? Improving Elementary knowledge within the context of a science methods course. Journal Science Teacher Education. 2014; 25: 953-976.

Schoon KJ, Boone WJ. Self-efficacy and alternative conceptions of science of pre-service elementary teachers. Science Education. 1998; 82:553-568.

SEI-DOST, UP NISMED. Framework for Philippine science teacher education. Taguig City: SEI-DOST and UP NISMED; 2011 [cited 2017 Apr 28]. Available from: http://www.sei.dost.gov. $\mathrm{ph} /$ images/downloads/publ/sei_sciteach.pdf

Shallcross T, Spink E, Stephenson P, Warwic P. How primary trainee teachers perceive the development of their own scientific knowledge: Links between 
confidence, content and competence?. International Journal of Science Education. 2002; 24(12): 12931312. doi: 10.1080/0950069110110106.

Shulman LS. Those who understand: Knowledge growth in teaching. Educational Researcher. 1986; 15(2): 4-14.

Supovitz JA, Turner HM. The effects of professional development on science teaching practices and classroom culture. Journal of Research in Science Teaching. 2000; 37(9): 963-980. doi:10.1002/10982736(200011) 37:9<963::AIDTEA6>3.0.CO;2-0

Swackhamer L, Koellner K, Basile C, Kimbrough D. Increasing the Self-Efficacy of In-service Teachers through Content Knowledge. Teacher Education Quarterly. 2009; 36(2): 63-78.

Tretter TR, Saderholm JC. Identification of the Most Critical Content Knowledge Base for Middle School Science Teachers. J Sci Teacher Education. 2008; 19:269-283. doi: 10.1007/s10972-008-9092-9.

Tschannen-Moran M, Woolfolk Hoy A. The differential antecedents of Self-efficacy beliefs of novice and experienced teachers. Teaching and Teacher Education. 2007; 23(6): 944 -956.

Tucay M. K-12: Who loses, who profits. Philippine Daily Inquirer [Internet]. 2015 June 7 [cited 2017 April 10]; Available from: https://opinion.inquirer. net/85551/k-12-who-loses-who-profits

Tupas T. SC urged to rule on bid to scrap K to 12 program. Inquirer.Net. [Internet]. $2017 \mathrm{Mar} 13$ [cited $2017 \mathrm{Feb} 4$ ]. Available from: https://newsinfo. inquirer.net $/ 880413 /$ sc-urged-to-rule-on-bid-toscrap-k-to-12-program

Van Driel JH, De Jong O, Verloop N. The development of pre-service chemistry teachers' pedagogical content knowledge. Science Education. 2002; 86(4): 572.

Voucher Program [Internet]. 2017 [cited 2017 April 11]. Available from http://www.deped.gov.ph/kto-12/faq/voucher-program

Wolters CA, Daugherty SG. Structures and teachers' sense of efficacy: Their relation and association to teaching experience and academic level. Journal of Educational Psychology. 2007; 99(1):181-193.

Zwiep S, Benken B. Exploring teachers' knowledge and perceptions across mathematics and science through content- rich Learning experiences in a professional development setting. International Journal of Science and Mathematics Education. 2013; 11:299-324. 